\title{
CAIS DE CHEGADA: A IMIGRAÇÃO NO CONTEXTO IBÉRICO. UMA ANÁLISE COMPARATIVA
}

\author{
Fátima VELEZ DE CASTRO - Fernanda CRAVIDÃO \\ CEGOT - Centro de Estudos de Geografia e Ordenamento do Território - \\ Universidade de Coimbra
}

Recibido: $16 / 03 / 2011$

Aceptado: 29/06/2011

RESUMO: Portugal e Espanha, dois países diferenciados no contexto intra e extraibérico, têm demonstrado similitudes nos seus percursos histórico-geográficos. Um dos aspectos que se pode salientar diz respeito à questão dos movimentos migratórios, tanto num contexto emissor como num contexto receptor. A época dos Descobrimentos e da colonização das províncias ultramarinas foi um dos primeiros momentos em que ambos os países assistiram à saída de população autóctone, assim como mais tarde, no início do século XX, ou depois, na segunda metade do mesmo século, em pleno período ditatorial vivido pelos dois países. A necessidade de assegurar as fronteiras estatais, a busca de melhores condições de vida (através do auferimento de melhores salários, por exemplo), muito em especial de liberdade política, económica e social - e a fuga a um contexto de guerra (colonial, no caso português e civil, no caso espanhol) - foram algumas das motivações que levaram portugueses e espanhóis a procurarem destinos transatlânticos, nomeadamente no continente Americano, Africano e também Europeu.

Mas a realidade migratória alterou-se e, a partir do último quarto do século XX, a Península Ibérica deixou de ser apenas cais de partida, para passar a ser também cais de chegada. Esta situação foi propiciada pela entrada de um contingente significativo de imigrantes de várias origens, com perfis diferenciados, que vieram alterar de forma marcante as paisagens de Portugal e Espanha.Com este trabalho pretende-se por um lado reflectir sobre a transição do paradigma migratório (os antecedentes, as circunstâncias motivacionais, os contextos geográficos...), e por outro perceber a dinâmica actual dos vários grupos imigrados em ambos os países, numa perspectiva comparativa. E se possível reflectir sobre o futuro da imigração ibérica tendo em conta o contexto de crise actual.

PALAVRAS CHAVE: Portugal, Espanha, emigração, imigração.

\section{“ARRIVAL DOCK”: IMMIGRATION IN THE IBERIAN CONTEXT}

ABSTRACT: Portugal and Spain, two different countries in the extra and intra-Iberian context, have demonstrated resemblances in their historic and geographic courses. One of the aspects which can be highlighted is concerned with the issue of migratory movements, both in a receiving and sending context. The era of the Descobrimentos and colonization of overseas provinces was one of the first moments when both countries witnessed the exit of autochthon population, as well as later, in the beginning of the $20^{\text {th }}$ century, or afterwards, in the second half of the same century, during dictatorial regime period of both countries. The need to assure State borderlines, the search for better life conditions (through better salaries, for exam- 
ple), especially the search for political, economical and social freedom - and the escape to a context of war (colonial in the Portuguese case and civil in the Spanish case) - were some of the rationales which lead Portuguese and Spanish to seek transatlantic destinations, namely in the American, African and European continents.

But the migratory reality changed and, from the last quarter of the 20th century onwards, the Iberian Peninsula stopped being only a shipping dock to also start being an arrival dock. This situation was made possible through the entrance of a significant contingent of immigrants of several origins with different profiles which changed the landscapes of Portugal and Spain drastically.

With this paper it is intended to reflect, on one hand, about the transition of the migratory paradigm (predecessors, motivational circumstances, geographical contexts) and, on the other hand, to understand the current dynamics of the several immigrated groups in both countries, in a comparative perspective. And, if possible, to reflect about the future of the Iberian immigration bearing in mind the current crisis context.

KEY WORDS: Portugal, Spain, emigration, immigration.

\section{BREVE INTRODUÇÃO}

Este artigo constitui um estudo preliminar sobre a evolução e situação da imigração no contexto geográfico da Península Ibérica no início do séc.XXI.

Partindo das reflexões de autores portugueses e espanhóis com trabalhos sobre a temática, assim como de fontes estatísticas (Serviços de Estrangeiros e Fronteiras, Instituto Nacional de Estatística), tentar-se-á realizar uma síntese das principais conclusões apresentadas, tendo em conta a realidade ibérica numa panorâmica histórica, um território que deixou de ser apenas cais de partida para se tornar num cais de chegada de estrangeiros que pretendem trabalhar e residir em Portugal e Espanha. Analisar-se-á a geografia da origem e do destino dos imigrantes, colocando-se em evidência a importância do mercado de trabalho ibérico para a (re)configuração dos fluxos a diferentes escalas. Além disso pretende-se discutir o futuro da imigração ibérica, tendo em conta o cenário de mobilidade actual.

\section{PERSPECTIVA COMPARATIVA ENTRE AMBOS OS PAÍSES: UMA BREVE REFLEXÃO HISTÓRICA}

Portugal e Espanha têm histórias migratórias muito similares, que se tocam inclusive em termos temporais e geográficos. Embora não se pretenda de todo fazer uma abordagem histórica exaustiva, não se pode deixar de referir o período dos Descobrimentos, onde ambos os países começaram a evidenciar sinais de querer encontrar e explorar novos territórios, processo esse incomportável do ponto de vista geoestratégico se não fosse a consolidação das possessões ultramarinas perpetrada pelos movimentos migratórios efectuados com os primeiros colonos. Nessa época os destinos são idênticos: em Portugal constitui-se como colónia o território que hoje corresponde a Cabo- 
Verde, S.Tomé e Príncipe, Guiné-Bissau, Angola, Moçambique, Brasil; em Espanha as possessões estendem-se da América Latina até à América do Sul (na actualidade do México ao Chile); na Ásia os portugueses chegam ao que hoje são países como o Sri-Lanka, Índia, Timor, China, Malásia. As marcas do que outrora foram estas primeiras migrações internacionais, se é que assim se podem chamar, prevalecem até hoje tanto no património históricoarquitectónico, como também na língua com o uso de vocábulos lusos e hispânicos, na toponímia e nos apelidos dos remotos descendentes, entre outros aspectos culturais.

Numa lógica histórica mais próxima da actualidade estes destinos mantiveram-se. No primeiro quartel do séc.XX, fluxos migratórios peninsulares orientavam-se para antigas/actuais colónias, sendo o continente americano principal receptor: de Portugal saem emigrantes para o Brasil, de Espanha saem emigrantes para a Argentina, Cuba, Venezuela e Chile. Como refere FERNÁNDEZ (2001: 26, 27), a primeira metade do séc.XX caracterizou-se pela existência de uma sociedade eminentemente agrária e emigrante, com um marcado êxodo rural, que se viria a prolongar em termos temporais, alimentando estes fluxos.

Mais tarde, o cenário do período posterior à Segunda Guerra Mundial também propiciou laivos comuns em Portugal e Espanha. Ambos os países viviam sob o clima de severas ditaduras políticas que emergiram na década de 30 do séc.XX e culminaram nos anos 70 do mesmo século (de 1933 a 1974, e de 1939 a 1976, respectivamente). As sociedades tinham a marca da ruralidade e da pobreza, pelo que no caso espanhol não se deve obliterar a fragilização política, social e económica deixada como herança de uma sangrenta guerra civil (1936-1939), a par de várias décadas de repressão política e social que perpetuaram e acentuaram este cenário. Havia uma Europa destruída pela guerra que se estava a reerguer, apresentando um mercado de trabalho emergente que necessitava de mão-de-obra barata sem grandes exigências em termos de qualificações académicas. França, Alemanha, Suíça, entre outros, tornaram-se destinos europeus dos fluxos emigratórios de ambos os países, sendo de destacar o indeterminado (mas supostamente elevado) número de imigrantes indocumentados. Também outros continentes como América e África foram territórios de destino dos fluxos emigratórios peninsulares.

O fim dos períodos ditatoriais e o processo de descolonização portuguesa, a par, já na década de 80 do séc.XX, da entrada para a então CEE, regeu o final/início de uma época em que ambos os países se começam a integrar na lógica europeia, criando-se condições sócio-económicas de crescimento e desenvolvimento peninsular. Verificou-se um aumento do investimento directo estrangeiro e dos investimentos públicos e privados, assim como a in- 
ternacionalização das economias portuguesa e espanhola. A liberdade política e social, a emergência das economias e dos mercados laborais, e mais tarde a adesão a Schengen, a par de outros factores de natureza antagónica como a posição geográfica na Europa e as políticas migratórias restritivas de países europeus tradicionalmente de imigração, tornam Portugal e Espanha destinos laborais atraentes na rota dos fluxos migratórios à escala global.

Portugal assiste à chegada de retornados num clima de migrações forçadas de fuga à Guerra Colonial já na década de 70 do séc.XX, mas também de naturais das ex-colónias africanas que deixam os respectivos países durante e após o processo de descolonização, no sentido de procurar novas oportunidades de ascensão económica e social. Também Espanha recebe imigrantes provenientes das suas ex-colónias da América Latina (Central e do Sul). No entanto, principalmente a partir do início do séc.XXI, os fluxos imigratórios em ambos os países, embora se devam salvaguardar as respectivas diferenças e contextos, têm vindo a aumentar em termos quantitativos, a par de uma diversificação das origens dos próprios indivíduos.

\section{A PENÍNSULA IBÉRICA: DE CAIS DE PARTIDA (TAMBÉM) A CAIS DE CHEGADA}

Quando se fala em primórdios dos processos imigratórios massivos em termos peninsulares, assume-se a década de 80 do século XX como aquela em os fluxos de imigrantes começaram a ganhar uma maior visibilidade, quer em termos quantitativos, quer em termos de diversificação das origens. Autores como Lopéz Trigal (1994: 17, 18), MARTíneZ, (1997: 103), ACtis, De PRADA e PEREdA (1999: 63), Blanco (2000:151, 153), PÉREZ (2002a: 21), VIEDMA e RODRIGUES (2005: 115) ou RAMOS (2004: 33) reflectem esta ideia, a qual parece generalizada na comunidade académica espanhola. Este último autor chama a atenção para o facto de, nos anos 80 do séc.XX, os académicos e os governantes ainda não encararem Espanha como um país receptor, mas sim como um país essencialmente emissor, embora à posteriori certos estudos tenham provado o contrário. Segundo a sua posição, só a partir dos anos 90 do séc.XX, se assume que Espanha se tenha tornado de facto num país de imigração.

Segundo VIERA, BUJÁn, CASAS e VARELA (2006: 22, 23), no caso espanhol, entre 1975 e 1997, o número de residentes estrangeiros em situação legal aumentou de 165.000 para cerca de 610.000 , o que implicou um crescimento anual de $10 \%$, tendo-se verificado um incremento generalizado de imigrantes, quer em termos de número, quer em termos de diversificação de nacionalidades. Num primeiro momento houve um predomínio de cidadãos europeus e também de latino-americanos, pelo que a imigração tradicional 
dos anos 70 do séc.XX era de argentinos, uruguaios, chilenos e venezuelanos, tendo-se no início do séc.XXI aberto para cubanos, dominicanos e peruanos, entre outros, nomeadamente cidadãos africanos (sobretudo marroquinos). A chegada de imigrantes, acaba por reflectir a mudança internacional do próprio país a "desenvolvido". Era necessário requerer capital e mãode-obra que se ocupava de tarefas consideradas do ponto de vista social como pouco satisfatórias para os autóctones, como se discutirá mais adiante. Entre 2000 e 2003 chegaram a Espanha entre 1.600 .000 a 2.000.000 de imigrantes. Este número igualou a intensidade dos processos emigratórios de espanhóis no início do séc.XX (entre 1912-1915 chegaram a sair 10-12 imigrantes por cada 1000 habitantes, ao ano). De qualquer forma, e mesmo a receber imigrantes há mais de 25 anos, mais de metade da população estrangeira tem menos de 4 anos de permanência (legal) no país, o que demonstra o carácter recente do processo.

Em Espanha a incidência da imigração foi escassa até aos anos 80 do séc.XX, daí que se compreenda que até à Ley de Extranjería de 1985, não existisse legislação geral que controlasse este fenómeno (havia apenas legislação dispersa), pelo que a sua entrada em vigor muda o panorama e marca uma nova etapa na situação dos estrangeiros. Passa a considerar-se a imigração como um fenómeno significativo da sociedade e do território, pelo que também se constata a necessidade de "organizar" os fluxos a vários níveis, tanto na parte legislativa - em termos teóricos - como também na parte executiva - em termos práticos, daí a realização de processos de regularização que permitiram conhecer melhor a população imigrada em termos de números, características e localização. Além disso por uma questão de cidadania, no sentido de regularizar não só mas também a permanência das segundas gerações, nas quais se verificavam casos de irregularidade em indivíduos que tinham nascido no país de acolhimento dos pais, mas que não eram considerados dessa nacionalidade.

O fim do séc.XX/princípio do séc.XXI fica marcado pela celebração de processos massivos de regularização de imigrantes, que reflectiram a aceleração dos fluxos com destino a Espanha, de $1996^{1}$ a 2001. O volume dessas legalizações resultou na duplicação do censo legal de residentes estrangeiros de países terceiros em Espanha. EsCRIBANO (2002: 43, 42) reconhece a ingerência destas regularizações extraordinárias, referindo também que a assi-

\footnotetext{
${ }^{1}$ Por exemplo, o crescimento entre 1990 e 1996 também é produto do processo de regularização de 1991, já que houve muitos imigrantes que entraram na segunda metade da década de 80 do séc.XX e que só naquele momento foram contabilizados.
} 
natura de acordos ${ }^{2}$ entre países (emissores e receptor) pode, de certa forma, ajudar a "controlar" as entradas, o que se irá reflectir em vários campos, nomeadamente no estatístico, uma vez que desta forma os números se poderiam aproximar mais da verdade, ou seja, do momento real da entrada dos imigrantes no país e do seu estabelecimento. Caso contrário continuar-se-á a falsear as estatísticas, isto é, a ter picos de imigração em anos de ocorrência de processos de regularização extraordinários, pelo que os elevados quantitativos contabilizados não terão relação com a entrada de novos imigrantes, mas sim com a legalização dos que já estavam no país há algum tempo em situação irregular.

No caso português, até ao início dos anos 90 do séc.XX, as questões relativas à imigração para Portugal também não constituíam uma temática central no domínio das preocupações académicas, científicas, ou até mesmo políticas e sociais. O país estava virado para a questão emigratória, questão mais visível e marcante do cenário migratório português (MARTINS, 2006: 28) ${ }^{3}$.

Autores como Baganha, Ferrão, Malheiros (1998: 89), Baganha, MARQUES, FonSECA (2000: 11), BAGANHA, MARQUES, GóIS (2009: 123) assumem que o fenómeno imigratório no país é algo recente. Portugal, tal como outros países do sul da Europa, também viu aumentar significativamente a entrada de imigrantes no princípio dos anos 80/ anos 90 do séc.XX. Até meados dos anos 70 do século referido, registou-se um número muito reduzido de imigrantes a viver em Portugal, sendo que o Censo de 1960 assinalava cerca de 29.000 indivíduos $^{4}$ nessa situação (67\% da Europa, 1,5\% de África, 22\% do Brasil).

ESTEVES (1991: 19-21) sistematiza a evolução da imigração em Portugal, referindo que o aumento da população estrangeira residente no país, a partir da segunda metade da década de 70 do séc.XX, tem como característica o

\footnotetext{
2 O autor faz referência à assinatura, em 2001, de três acordos para regular os fluxos com o Equador, Colômbia e Marrocos, e também com a Polónia, Roménia e República Dominicana, com o objectivo de prevenir situações de clandestinidade geradoras de exploração. Os acordos teriam como linhas orientadoras a comunicação das ofertas de emprego às embaixadas (com base nas necessidades de mão-de-obra espanhola); a selecção dos candidatos com a participação dos empregadores (incluindo a preparação da sua viagem e estadia); a elaboração de disposições especiais para trabalhadores temporais; a ajuda ao retorno voluntário.

${ }^{3}$ SANTOS (2004: 107) é outro autor que também refere que, em termos estatais, o reconhecimento de Portugal como país de imigração surge com o IX Governo Constitucional, no período que sucede a entrada de Portugal (e Espanha) na CEE. Este discurso oficial vai-se consolidar a partir do início dos anos 90 do séc.XX.

${ }^{4}$ Estes autores estimam que pudessem viver em Portugal, na mesma data, até 30.000 estrangeiros.
} 
lento e regular crescimento do fluxo proveniente da América e da Europa, e a aceleração brutal (sobretudo entre 1976 e 1980) da imigração originária dos PALOP. A autora assume que houve uma estagnação do quantitativo de população estrangeira residente em Portugal durante os anos 50 e a primeira metade da década de 60 do séc.XX, efeito das concepções autárcicas e isolacionistas que, do ponto de vista político, económico e social, marcaram esse período da história portuguesa. Os poucos estrangeiros residentes eram reformados ou indivíduos integrados em sectores de actividade bem específicos (comércio de vinho do Porto ou minas, sendo que a sua presença já remonta a períodos mais recuados da história portuguesa). Em 1960 o grupo mais numeroso era o da Europa (67\% dos estrangeiros), com destaque para Espanha (40\%), Grã-Bretanha (7\%), França (6\%), Republica Federal da Alemanha (5\%), seguido da América $\left(31 \%^{5}\right)$, África (1,5\%), Ásia e Oceania $(0,8 \%)$.

Com a industrialização e a entrada de Portugal para a EFTA ${ }^{6}$ durante a segunda metade da década de 60 do séc.XX, começa a haver uma abertura do país ao exterior. Entram capitais estrangeiros para sectores como o turismo (que se começa a desenvolver no Algarve), onde se vão fixar em número crescente ingleses e alemães. Há também a entrada de estudantes do que hoje são as antigas colónias para fazerem os seus estudos universitários, bem como de trabalhadores não qualificados recrutados em Cabo-Verde para fazer face à escassez de mercado no sector da construção civil, resultante do deficit de população activa masculina, assegurando-se como massa crítica essencial para perpetrar de forma continuada a participação portuguesa na guerra colonial $^{7}$.

MALHEIROS (1996: 59, 60, 79, 203; 2005:103) e ROCHA-TRINDADE (1995: 199) também chamam a atenção para alterações contextuais verificadas. A implementação da democracia em países como Portugal, Espanha e Grécia na década de 70 do séc.XX, foi acompanhada por um processo de transformações económicas que favoreceram a atracção de imigrantes, e que resultou num aumento dos salários e em melhorias em diversos campos laborais e sociais (segurança no emprego, progressivo aumento das reformas, difusão dos serviços de educação, saúde, assistência social, entre outras). A partir daí

\footnotetext{
${ }^{5}$ No cômputo dos oriundos do continente americano, os brasileiros representavam $22 \%$ do total.

${ }^{6}$ European Free Trade Association.

${ }^{7}$ É difícil realizar uma contabilização deste contingente dos PALOP (Países Africanos de Língua Oficial Portuguesa), uma vez que estes fluxos eram considerados inter-regionais e não internacionais, daí a não existência de estatísticas específicas nesse sentido.
} 
nota-se um crescente número de estrangeiros em Portugal, embora se reconheça que a presença de mão-de-obra africana (proveniente de Cabo Verde) date já dos anos 60 do séc.XX, quando a emigração e a guerra colonial reduziram o contingente de homens para trabalhar em sectores como a construção civil e foi preciso recorrer a mão-de-obra alóctone, como já foi referido. A visibilidade das comunidades estrangeiras só começou a ser significativa a partir de meados dos anos 70 do séc.XX.

O contexto de conflito ultramarino e, sobretudo o seu desfecho, contribuiu de forma decisiva para a determinação dos primeiros movimentos imigratórios portugueses. Jorge MALHEIROS defende que a mudança do regime político em 1974, o fim da guerra colonial e o processo de descolonização, fazem com que retornem ao país não só portugueses emigrados, como também retornados e nacionais das ex-colónias.

Mas este novo cenário não trouxe apenas indivíduos com a situação de imigrante regularizada. FONSECA (2005: 83) chama a atenção para a intensificação dos fluxos nos anos 80 do séc.XX, tanto os de índole legal como os indocumentados, fazendo parte dos mesmos um grande contingente de população dos PALOP. Nesse sentido, tal como acontecera em Espanha, houve necessidade de organizar as entradas e as permanências, daí terem-se empreendido duas campanhas de legalização extraordinária, uma em 1991/1992 e outra em 1996. O gráfico $1^{8}$, o qual sintetiza de certa forma as reflexões até aqui realizadas, dá a conhecer a evolução da população estrangeira residente em Portugal e em Espanha, desde o início da década de 80 do séc.XX, quando se começa a intensificar o fenómeno imigratório em ambos os países, até à actualidade.

Pela observação das curvas há algumas questões que parecem evidentes ${ }^{9}$. A primeira é que ambos os países apresentam durante a década de 80 e parte da década de 90 do séc.XX, uma evolução semelhante nos contingentes migratórios, isto é, apesar de se afastarem em termos quantitativos (Espanha apresenta valores absolutos de imigração mais elevados que Portugal), é nos

\footnotetext{
${ }^{8}$ Para a curva de distribuição portuguesa consideraram-se os cidadãos estrangeiros com permanência regular em território nacional (até 1995 só contam os títulos de residência, e entre 2005-2007 os títulos de residência, as prorrogações de autorização de permanência e as prorrogações de vistos de longa duração). Para a curva de distribuição espanhola fora considerados os estrangeiros residentes no país, detentores de certificado de registo ou visto de residência válidos em 31/12/07.

${ }^{9}$ Para o ano de 2008, o Serviço de Estrangeiros e Fronteiras referia existirem em Portugal 440.227 imigrantes residentes. Já para a mesma data em Espanha a Secretaria de Estado de Inmigración y Emigración referia a existência de 4.473.499 imigrantes residentes, embora o Padrón Municipal (INE-ES) referisse a existência de 5.043137 imigrantes residentes.
} 
anos 80 do séc.XX que começam a receber imigrantes em termos significativos e é a partir de meados da década de 90 do séc.XX/início do séc.XXI que se dá uma entrada sem precedentes de migrantes estrangeiros. Este facto é constatável em ambas as curvas, embora no caso português o aumento seja mais paulatino, enquanto o espanhol demonstra um aumento muito marcado.

Gráfico 1. Evolução da populacão estrangeira residente em Portugal e em Espanha, de 1980 a 2007

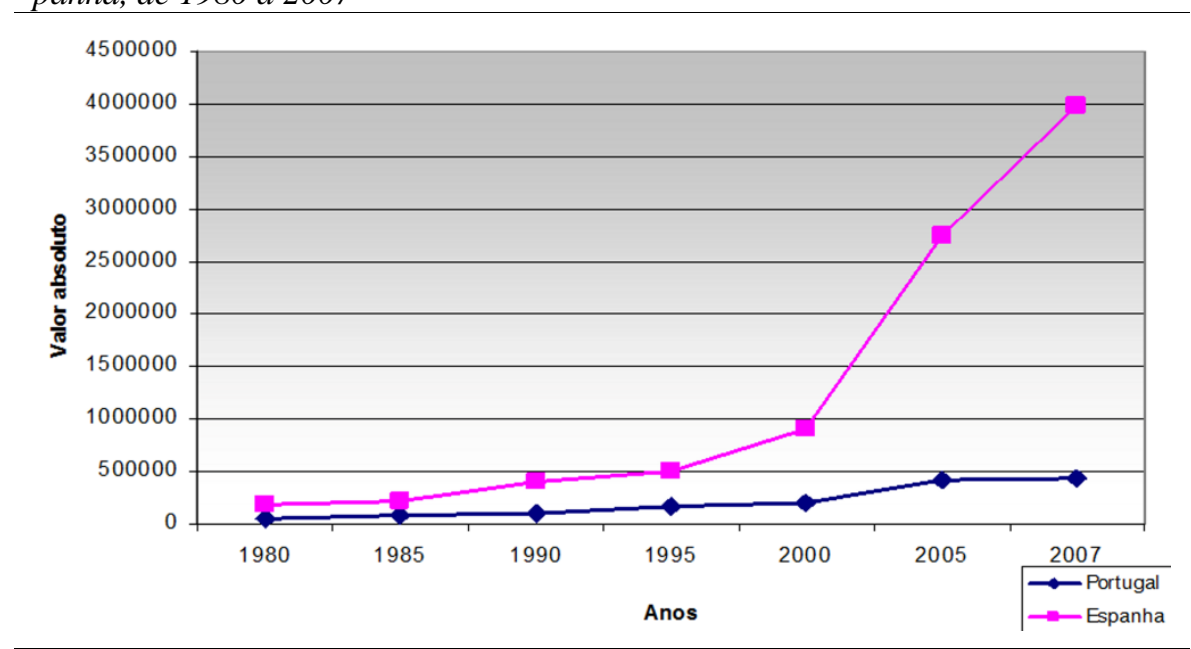

Adaptado de MARTínez (2003), SEF (2009) - Estatísticas Gerais, SEIE - Anuários (2009)

Para se ter uma ideia, veja-se que em 1980 Portugal tinha 50.750 imigrantes residentes enquanto Espanha já tinha 182.045 imigrantes residentes. Em 1995 Portugal consegue superar o anterior valor do país vizinho, registando a presença de 168.316 imigrantes residentes, contudo Espanha já apresenta 499.773 imigrantes residentes. Em 2008 Portugal apresenta um número superior aos anos anteriores - 440.277 imigrantes residentes, numa lógica oscilante de diminuição (anos de 2005 e 2006) e de recuperação (anos de 2007 a 2009) do contingente. Em Espanha dados de 2008 confirmam a continuação do aumento do contingente imigratório no país - 4.473.499 imigrantes residentes. De 1995 para 2008, a população imigrante residente em Espanha aumentou 9 vezes, enquanto em Portugal no mesmo período temporal aumentou pouco mais de 2,5 vezes. Embora se esteja perante contingentes diferenciados, pode constatar-se que enquanto noutros países o aumento do número de imigrantes foi lento e o fenómeno imigratório se desenvolveu em grandes períodos temporais, Espanha passou de país emissor a receptor praticamente numa década e de maneira mais intensa no corrente século, tendo de certa forma ocorrido o mesmo em Portugal (SECRETARIA CONFEDERAL DE MIGRACIONES, 2006: 5). 


\section{III.1. A população imigrante e a sua expressão no contexto socio- demográfico nacional e internacional europeu}

Gráfico 2. Evolução da percentagem de estrangeiros na população total em Portugal e em Espanha, de 1981 a 2007

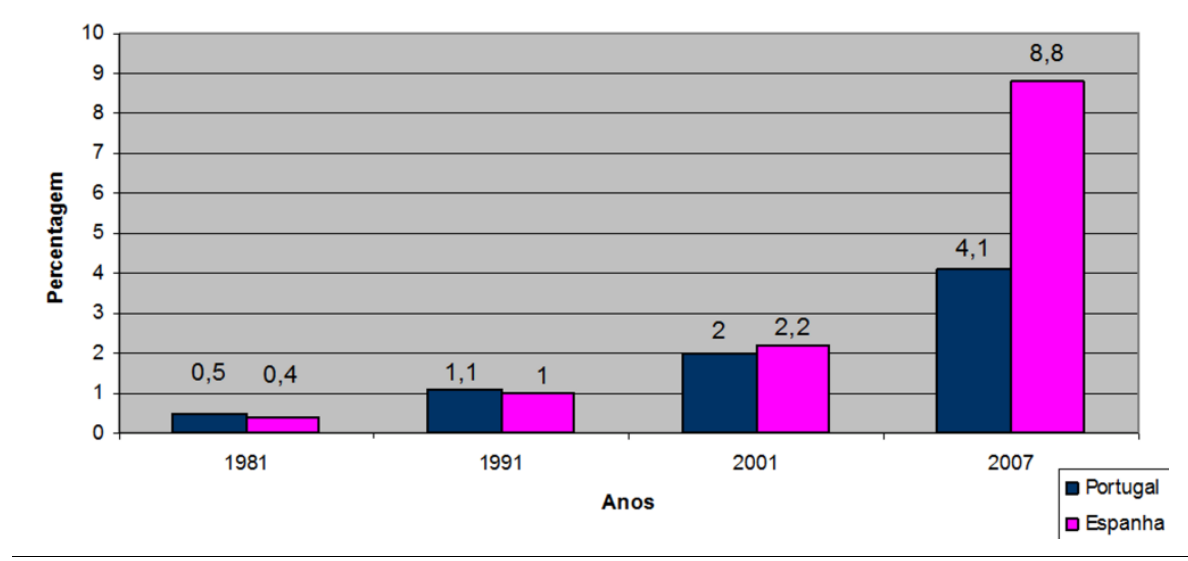

Elaboração própria (2009)

Assumindo, como já foi discutido, a condição de receptores, será pertinente neste contexto consolidar este pressuposto através da análise do peso da população imigrante na população total de cada país.

No que diz respeito à evolução da presença de estrangeiros na população total em Portugal e Espanha, de 1981 a $2001^{10}$, corrobora-se o aumento da população imigrante em relação com a população de cada um dos países. Portugal chega a ultrapassar a Espanha em 1991, quando por cada 100 habitantes existia, em média 1,1 imigrantes. Contudo em 2007 esse valor praticamente duplicou (2\%) em Portugal e em Espanha disparou, uma vez que por cada 100 residentes, passa a haver cerca de 9 imigrantes residentes ${ }^{11}$.

Perante os números apresentados pode concluir-se que ambos os países são destinos migratórios com um nível de procura significativo no contexto da Europa do Sul. Porém, na bibliografia referente a Portugal e Espanha, sobretudo na espanhola, os autores tendem a questionar-se sobre a relevância deste quantitativo no contexto Europeu. O Eurostat dá-nos um retrato actual da situação, tendo em conta os imigrantes que entraram em vários países euro-

\footnotetext{
${ }^{10}$ Os cálculos foram feitos com base nos dados sobre estrangeiros do SEF (2009) e do INE Espanha (2009) de 1980, 1990 e 2000, mas com a população total de 1981, 1991 e 2001.

${ }^{11}$ Em 2008 o valor manteve-se para Portugal $(4,1 \%)$, embora para Espanha tenha aumentado de forma significativa $(9,7 \%)$.
} 
peus, bem como a média da UE 27 , no ano de 2006. Num grupo de 28 países e da média da UE, constata-se que Espanha está em $4^{a}$ lugar em termos do número de imigrantes que entraram no país nesse ano - 18,1 indivíduos por cada 1000 habitantes nacionais. Sublinhe-se que fica à frente de países com forte tradição imigratória como a Suíça $(14,2 \%$ ), o Reino Unido $(7,4 \%$ \% ou a Alemanha $(6,8 \%)$. Portugal ocupa a $19^{\text {a }}$ posição $(2,6 \%)$ em 28 casos em análise, seguindo a França $\left(2,9 \%\right.$ - $18^{\circ}$ posição). Também países de tradição imigratório como a Grécia $\left(7,6 \%\right.$ - $10^{\circ}$ posição) e Itália $\left(6,8 \%\right.$ - $\left.12^{\mathrm{a}}\right)$ ocupam posições cimeiras enquanto destinos receptores no contexto da União Europeia. Perante esta análise verifica-se que os destinos europeus dos fluxos migratórios se estão a diversificar, embora seja questionável se os valores de um ano apenas poderão dar essa ideia, bem como justificar a alteração hierárquica da posição de países como Portugal e Espanha no contexto europeu, como receptores de fluxos imigratórios.

\section{A GEOGRAFIA DOS IMIGRANTES: DA ORIGEM AO DES- TINO}

A geografia da imigração portuguesa e espanhola tem mantido desde os anos 80 do séc.XX um padrão distributivo mais ou menos constante. Pode dizer-se assim porque, de uma forma geral, os imigrantes seguem a tendência dos autóctones ao procurarem territórios onde os níveis de concentração populacional são maiores - áreas metropolitanas das capitais (Lisboa e Madrid), bem como outras áreas urbanas litorais. Tal facto está relacionado com as características do tecido económico destas regiões, assim como pelas mais variadas oportunidades geradas pelo mercado de trabalho.

BLANCO (2000: 153), referindo-se ao caso de Espanha, afirma que nos anos 80 do séc.XX a região receptora por excelência era Madrid, seguida da Catalunha, Comunidade Valenciana, Andaluzia e Baleares. Nestas regiões viviam $80 \%$ dos imigrantes espanhóis. Também VIEDMA e RODRíGUES (2005: 123) e FERNÁNDEZ, COLL e HITA (2006: 120-123) fazem uma análise da distribuição espacial actual da população estrangeira em Espanha, comprovando que existe um grande nível de concentração regional. Distinguem regiões onde a presença de imigrantes residentes é mais forte: em Madrid (22\%); no corredor de Girona (com alguma diminuição dos valores em Granada), que inclui a região de Barcelona (15\%), Alicante (9\%), Girona (3\%), Alméria (2\%), Málaga (5\%), Múrcia (4\%), e também Castellón (2\%), Tarragona (2\%) e Valência (6\%); nas ilhas Baleares (4\%), arquipélago das Canárias $(3 \%)$. Os autores chamam também a atenção para a presença de imigrantes em Ceuta e Melilla, assim como no eixo do Ebro (Zaragoça, Navarra e La Rioja), na área de influência de Madrid (Guadalajara e Segóvia) e em Leyda. Em suma, as 10 províncias com maior número de imigrantes reúnem 
3/4 do total, sendo que as províncias de Barcelona e Madrid reúnem cerca de $40 \%$ dos estrangeiros que se estabeleceram no país nos últimos anos.

Mapa 1. Distribuição geográfica da população estrangeira a residir e trabalhar em Portugal e Espanha, em 2009

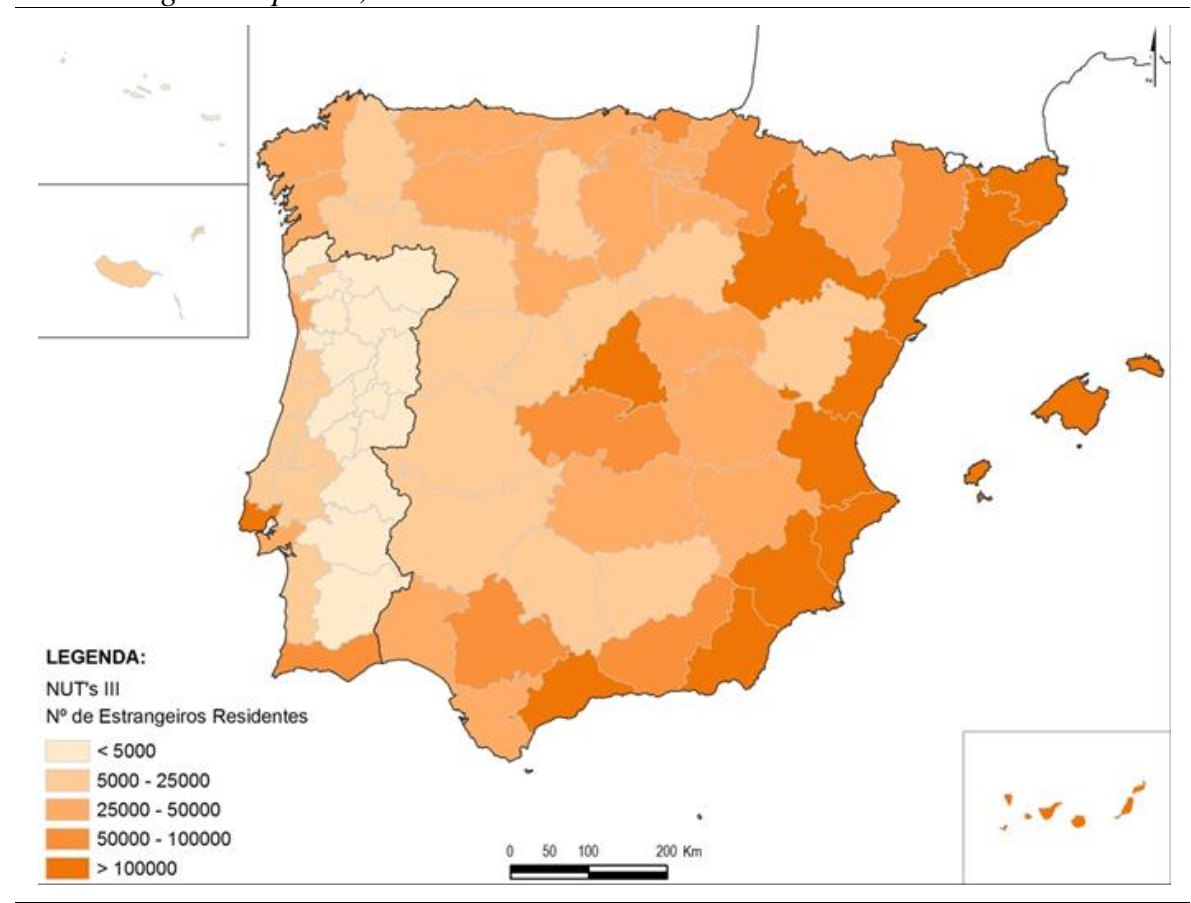

Elaboração própria (2011)

Nota-se que o contingente de estrangeiros registou um crescimento de $12 \%$ de 1998 a 2006, sendo de destacar os maiores aumentos nas comunidades autónomas de Múrcia, La Rioja, Castilla-la-Mancha, Aragón e Navarra (sendo que 3 destas comunidades são uniprovinciais). De qualquer forma o aumento do número de imigrantes foi sentido por todas as comunidades autónomas do país (IKUSPEGI, 2007: 1,2).

No caso português a faixa litoral entre Setúbal e Braga, bem como o Algarve, a Área Metropolitana de Lisboa e do Porto, são as regiões onde se concentra a maior parte dos imigrantes no país. MEDEIROS (1996: 144) e FONSECA $(2005: 81,87)$ referem que a imagem geral do país é a de uma forte litoralização da imigração, acompanhando e acentuando as assimetrias regionais da distribuição da população portuguesa. No final de 2002, cerca de $83,4 \%$ do total de população estrangeira vivia nos distritos de Lisboa, Faro, Setúbal e Porto. Fora destas áreas Maria Lucinda FonSECA salienta os distri- 
tos do litoral continental (Aveiro, Coimbra, Braga e Leiria), e as Regiões Autónomas dos Açores e Madeira com concentrações significativas de imigrantes.

Pela observação cartográfica de ambos os países, confirma-se a litoralização peninsular no que diz respeito à distribuição dos imigrantes, no entanto esta não é generalizada, já que a concentração é mais notória no litoral mediterrânico e em certas partes atlânticas, donde se exclui o litoral alentejano e a costa norte e noroeste da Península Ibérica. No interior desta unidade territorial apenas se destaca Madrid com um grande quantitativo de imigrantes.

Contudo é de ter em atenção que também o interior da Península Ibérica, embora mais desprovido de população autóctone e de imigrantes, se apresenta como área receptora de segunda linha. Na base deste fenómeno está a reestruturação da economia, a terciarização das economias portuguesa e espanhola, o aumento da taxa de actividade feminina, que deixa livres para os imigrantes funções no segmento secundário laboral. Tal acontece não só nos principais centros urbanos, como nos mercados laborais locais do interior da Península.

Baganha, Marques e Fonseca (2000: 12), Fonseca, Malheiros, ESTEVES e CALDEIRA (2002: 101), VELEZ DE CASTRO e CRAVIDÃo (2008: 284) reconhecem que ultimamente as regiões do interior começam a conhecer o fenómeno da imigração. A pressão demográfica na área metropolitana de Lisboa tem feito com que alguns imigrantes se dispersem para áreas mais interiores do país, procurando aproveitar oportunidades de trabalho em mercados locais. Os brasileiros por exemplo deslocam-se para o interior norte, ligados a ancestrais conexões familiares, contudo também para outros locais do país tal como os imigrantes do Leste europeu. Embora exerçam as mesmas profissões que exerceriam nas áreas litorais, aqui podem desempenhar tarefas em pequenas indústrias, na indústria extractiva, e na agricultura tal como acontece em Espanha (embora esteja mecanizada, há tarefas que não dispensam a mão-de-obra nomeadamente as vindimas, a apanha da fruta, da azeitona, entre outras). Os chineses têm procurado as cidades do interior e outras pequenas localidades com os seus restaurantes e bazares, aproveitando as vantagens resultantes do preço mais reduzido do arrendamento de habitações e lojas nesses locais, relativamente às cidades do litoral, bem como a exploração de um novo mercado de consumidores.

FONSECA (2005: 94) também assume uma tendencial dispersão para o interior do país relatando situações esporádicas (por exemplo o caso de Mourão, aquando da construção da Barragem do Alqueva) em que determinadas re- 
giões recebem contingentes significativos de imigrantes, situação também reconhecida por MALHEIROS (2005: 110-111) e BAGANHA, MARQUES e GóIS (2009: 127). Nota-se uma dispersão geográfica de Lisboa e Setúbal para outros distritos litorais (Porto, Aveiro, Leiria), para o interior (Évora) e a consolidação do contingente imigratório no Algarve, o que está associado a vários factores. No Alentejo, a quebra da natalidade e fecundidade e o envelhecimento geram carências de mão-de-obra em sectores como a construção civil e a agropecuária. No Norte Litoral a construção civil (Porto Capital da Cultura e Euro 2004) requereram mão-de-obra, conjugada com a percepção de alguns empresários relativamente a uma eventual maior capacidade dos imigrantes de Leste no acompanhamento (relativamente aos autóctones) da reestruturação organizativa e tecnológica das suas fábricas, aliado a uma possível menor disponibilidade dos nacionais realizarem determinado tipo de tarefas em certas condições (por exemplo, turnos nocturnos). Neste contexto, a expansão do consumo e a dinâmica das cidades médias do interior vieram oferecer maiores possibilidades em sectores como o comércio (enclaves étnicos dos chineses) e o turismo, o que acabou por ser coadjuvado pelo desenvolvimento de redes de entreajuda à imigração. Enquanto a comunidade dos PALOP está fortemente ancorada na Área Metropolitana de Lisboa, os Europeus de Leste e Brasileiros estão mais dispersos e por isso alimentam essa mesma dispersão ao facilitarem a migração de compatriotas para áreas fora das tradicionalmente receptoras de imigrantes.

No que diz respeito ao caso espanhol PÉREZ (2002b:173, 174), RAMOS, (2004: 41) FERNÁNDEZ, COLL e HiTA (2006: 123-207) e o Observatório Basco de Imigração-IKUSPEGI (2007: 2) afirmam que a disposição geográfica dos imigrantes coincide com as regiões mais dinâmicas do ponto de vista económico, considerando também a habitação como um factor articulador da redistribuição interna (preços de rendas mais baixos na periferia ou em áreas menos valorizadas das cidades). $\mathrm{O}$ turismo e também a agricultura são sectores que levam muitos imigrantes a procurar as províncias do litoral, no caso deste último onde dominam as culturas hortofrutícolas, ou até províncias mais interiores como La Rioja, Navarra ou a Estremadura com culturas mais específicas (desde a vinha, aos espargos, tabaco, tomate, entre outras, conforme a região em causa).

Em termos de origem/destino os autores reconhecem que os LatinoAmericanos são o grupo mais numeroso a residir em Espanha, destacando-se a sua forte concentração em Madrid e Barcelona, bem como em Múrcia, Valência, Alicante, Baleares e Las Palmas ${ }^{12}$. Os Europeus, como segundo

${ }^{12}$ ViedMA e RodRíGUeS (2005: 124) destacam o nível de dispersão do grupo, afirmando 
grupo mais numeroso, têm um padrão bi-segmentado. Os cidadãos da União Europeia estão em maior número nas Baleares, em Santa Cruz de Tenerife, Las Palmas, Alicante, Málaga, Cádiz e Orense, ou seja, em encalves turísticos de maior tradição. As nacionalidades da Europa extra-UE distribuem-se, além das regiões com maior concentração como Madrid e Barcelona, também por Castellón, Teruel, Segóvia, Valladolid e Valência ${ }^{13}$. Neste conjunto de regiões mencionadas vivem $3 / 4$ do grupo dos europeus. Os Africanos, concentram-se em Barcelona, Madrid, Girona, Tarragona, Lleida, Huesca, Almería, Jaén, Huelva, Cáceres, bem como Ceuta e Melilla, assim como os Asiáticos se concentram em Barcelona e Madrid, assim como em Valência, Las Palmas, Málaga, Alicante e Santa Cruz de Tenerife.

Em suma, Barcelona e Madrid são as regiões que concentram um maior contingente de imigrantes de todas as nacionalidades. De uma forma geral, as províncias situadas na costa mediterrânica, em conjunto com as ilhas Baleares e Canárias, têm uma concentração substancial de imigrantes, embora se note alguma dispersão para o interior (por exemplo no caso dos africanos).

Em termos intra-nacionais movimentos intraprovinciais são mais generalizados, enquanto os interprovinciais são mais masculinizados, uma vez que também são uma estratégia individual (não tanto de cariz familiar). Os níveis de mobilidade interna dos imigrantes são maiores do que os dos autóctones, uma vez que os primeiros buscam melhores condições de trabalho. Note-se que se os imigrantes terão mais propensão para migrar internacionalmente, também terão mais propensão para o fazer a nível interno, uma vez que podem ter "menos a perder", isto é, não têm ligações patrimoniais (por exemplo, pagamento prestação de empréstimo para a compra de casa) e familiares do país de origem (caso de parentes mais idosos), factores que limitam a mobilidade dos autóctones.

Só nalguns casos é que os níveis de migração interna dos autóctones são superiores aos dos imigrantes, quando a qualificação profissional é maior ou têm mais possibilidades económicas e sociais para colocar em marcha o processo migratório. Este aumento da mobilidade interna também tem a ver com o próprio aumento de imigrantes no país, embora como já se viu, esta não seja a causa única.

que os latino-americanos são mais do que $1 / 4$ do total de imigrantes em Espanha e estão presentes praticamente em todas as comunidades autónomas (excepto em Ceuta e Melilla).

13 Os autores citam VirUEla (2002) que fala mesmo da "romenização" da província de Castellón. 
Para o futuro próximo Pablo FERNÁNDEZ, Arlinda Coll e Ángeles HITA prevêm-se que Madrid e Barcelona continuarão a ser os principais reguladores dos fluxos migratórios, com a consolidação das províncias que apresentam concentrações significativas de imigrantes (Girona, Múrcia, Tarragona). Distinguem porém a emergência de dois tipos de províncias: as emergentes (interior do país) e as selectivas (nos seus fluxos). Para o caso destas últimas, os autores exemplificam com o caso de Almería como área emissora/redistribuidora (onde há a saída de africanos e a entrada de latinoamericanos e europeus comunitários), e Badajoz e Huesca como áreas receptoras (de argelinos, marroquinos e mauritanos), fruto das alterações da oferta e da procura do mercado-de-trabalho.

Os autores também identificam um terceiro tipo, ou seja, a possibilidade do desenvolvimento "províncias de exploração" (por exemplo, a Extremadura), as quais têm menor dinamismo económico, menor presença de compatriotas, menor competência laboral, e por isso menos concorrência e a possibilidade desenvolvimento de nichos de mercado pouco explorados.

\section{A DINÂMICA DO MERCADO DE TRABALHO IBÉRICO NA RELAÇÃO COM A GEOGRAFIA DAS MIGRAÇÕES}

Numa perspectiva comparativa, será também interessante explorar a questão do mercado de trabalho ibérico na relação com a mão-de-obra imigrante, na medida em que esta dimensão se apresenta como móbil decisivo na escolha do destino (possível) da migração, a qual acaba por organizar e gerir a própria geografia dos fluxos dentro do próprio território peninsular.

A complexidade do tema poderia comprometer a natureza da abordagem efectuada. Porém, para que se assegure com uma lógica coerente e assertiva, optar-se-á por excluir as migrações de altos quadros profissionais, os quais mantêm o seu tipo de emprego/desempenho de funções no país de destino. Neste sentido fará sentido a abordagem de duas áreas laborais que têm atraído muitos dos imigrantes ibéricos, ou seja, a globalidade das migrações de indivíduos pouco qualificados ou mesmo qualificados, mas que desempenham no destino funções completamente desadequadas à sua formação profissional - a agricultura e os serviços.

Quando este tipo de migrantes chega ao destino da sua migração, neste caso Portugal ou Espanha, embora a situação se possa repetir noutros territórios, têm como intenção recuperar a despesa efectuada no processo migratório (custos decorrentes da documentação, da viagem, entre outros aspectos), estabelecer-se e estabilizar (o que acarreta custos em termos de habitação arrendamento, escola para os filhos...) e começar auferir capital decorrente 
de um emprego/trabalho para suprir as suas despesas, poupar, enviar como remessas para o restante agregado familiar que ficou no país de origem ou ainda para investir (num negócio por conta-própria, na banca, na compra de bens imobiliários, entre outros). Este é o retrato elementar do projecto migratório.

Todavia, para que se possam cumprir estes desígnios, o migrante acaba por necessitar de se adaptar às condições conjunturais do mercado de trabalho, evidenciando sinais de resiliência tanto face ao tipo de trabalhos/empregos/funções disponíveis, como tendo em conta a própria concorrência com os autóctones/outros imigrantes. Neste sentido estão patentes os princípios da teoria do mercado de trabalho segmentado, a qual defende que, de uma forma geral, os imigrantes tendem a ocupar no mercado laboral os lugares deixados vagos pelos nacionais, que preferem desempenhar tarefas mais bem pagas e que confiram status do ponto de vista social, deixando para os alóctones tarefas mais mal pagas e mais desgastantes, e por isso pouco reconhecidas socialmente.

Desta forma reconhece-se a presença de imigrantes em sectores cujas funções que desempenham não exigem mão-de-obra qualificada. Tal acontece na agricultura, uma das actividades onde a concentração de mão-de-obra imigrante é muito significativa, sobretudo no caso espanhol, onde são comuns os contingentes de marroquinos, romenos, equatorianos, búlgaros e bolivianos. No português também acontece, embora se apresentem como situações mais esporádicas, podendo-se encontrar brasileiros ou imigrantes do Leste europeu assalariados rurais (por conta de outrem) como caseiros ou na vinha (entre outras funções), ou então imigrantes europeus (o caso dos neerlandeses) proprietários de explorações agrícolas e pecuárias. Este fenómeno está intimamente relacionado com o êxodo agrícola e com o êxodo rural, que resultou na deslocalização das populações do sector primário e de local de residência, o que se reflectiu num abandono das áreas rurais e das actividades agrícolas e pecuárias relacionadas. Perante as necessidades de mão-deobra, e face ao fraco reconhecimento social que este sector de actividade passou a representar, os imigrantes acabaram por ocupar estes lugares deixados pelos autóctones.

A agricultura, assim como determinadas funções noutras áreas laborais (serviços domésticos), empregam muitos imigrantes em Espanha e que, podendo ser considerados atractivos, pelo menos como uma experiência transitória (pode tornar-se definitiva) até conseguirem aceder a outro tipo de trabalhos (no sector secundário e terciário), com melhor remuneração e com jornadas de trabalho menos exigentes (SECRETARIA CONFEDERAL DE MigRACIONES, 2006: 13, 14). No caso da agricultura muitas vezes não se 
tratam de emprego, mas sim de trabalhos a que os imigrantes acedem sazonalmente, já que muitos destes trabalhadores realizam migrações internas entre comarcas/províncias, seguindo o calendário agrícola, numa lógica de obtenção de capital e de espera pela regularização burocrática, pelo que grande parte se tratam de indocumentados. PÉREZ e TRIGAL (1999: 213-221) estimaram que no final do séc.XX, a agricultura empregasse cerca de 25.000 estrangeiros nesse país, a maior parte oriundos do continente africano e em situação irregular, embora também se pudessem encontrar portugueses.

Destes 25.000 , cerca de $3 / 4$ concentram-se na região de Barcelona, Almería e em Múrcia. A difusão destes jornaleiros foi muito rápida em Espanha nos anos 80 e 90 do séc.XX, especialmente em áreas de cultivo de regadio e arborícola mediterrânico. Neste contexto também se destaca a comarca de Maresme como enclave mais importante da Catalunha o qual recebe imigrantes subsarianos desde os anos 70 do séc.XX, El Baix Llobregat, Tarragona, Segrià, mais a sul a Comunidade Valenciana (na apanha da fruta, na vinha e em estufas), Múrcia que no final do séc.XX reunia o maior contingente de estrangeiros (sobretudo de marroquinos) a trabalhar na agricultura de regadio (hortaliças e fruticultura), e a Andaluzia (Huelva, Granada onde trabalham na recolha de azeitona, nas culturas hortícolas - alface, tomate, couve-flor, alcachofra, entre outros produtos).

Mas as oportunidades de trabalho não estão apenas confinadas às áreas urbanas ou, neste caso, às regiões com maior importância em termos agrícolas. Alguns territórios do interior começam a ver aumentado o seu contingente de imigrantes na agricultura, como é o caso de Cáceres e da Estremadura em geral, onde os estrangeiros trabalham no cultivo de cereja, tabaco e espargos. PÉREZ e TRIGAL (1999: 226) também reconhecem que as pequenas localidades do interior da Península Ibérica têm oferecido dezenas ou até mesmo centenas de empregos na agricultura, segundo os autores, não só para autóctones como também para estrangeiros. É disso exemplo a apanha de cereja no Valle do Jerte, de tabaco e espargos em La Vera (província de Cáceres), nas plantações de tomate nas Vegas do Guadiana (província de Badajoz), de espargos, batata e na vinha em La Rioja, Navarra, Burgos e País Basco (Álava).

O sector dos serviços como actividade laboral de concentração de imigrantes, é muito atractivo sobretudo para o sexo feminino (ligado aos serviços de limpeza), destacando-se também o crescimento do emprego de imigrantes no ramo do comércio e da hotelaria (PAJARES, 2001:147-149). Este autor destaca os serviços domésticos como uma grande fonte de empregos para equatorianos, colombianos e bolivianos, bem como dominicanos e ucranianos, embora se revele uma área de actividade extremamente precária (só 7,7\% dos 
imigrantes registados na Segurança Social afirmam desenvolver funções nesta área). Em Portugal este sector é transversal praticamente a todas as principais nacionalidades presentes no país, sobretudo africanos, brasileiros e europeus de Leste, também com predomínio feminino no desempenho das funções. Mas o sector dos serviços é bastante complexo, tal como acontece em Espanha, já que está relacionado com um segmento que se refere a funções de baixas qualificações (serviço doméstico, venda ambulante, empregos sazonais na hotelaria...), mas também com "ocupações de alto status" (sector financeiro, administração pública, ensino...), ocupadas sobretudo por imigrantes da União Europeia (ACTIS, DE PRADA, e PEREDA, 1994: 106, 107; ESCRIBANO, 1992: 38-46). De sublinhar que este último grupo é também o que apresenta uma taxa de inactividade mais elevada (sobretudo britânicos, suecos e franceses), se comparada com outros grupos de imigrantes. Mais de metade dos imigrantes comunitários são inactivos, o que, associado à idade média deste grupo (acima de 45 anos), leva a crer que procuram o país já enquanto reformados, para desfrutar dos rendimentos obtidos ao longo da vida activa, com maiores vantagens económicas, sociais e climáticas do que nos respectivos países de origem (FrANCISCO, RABANAL, SÁNCHEZ, e LA IGLESIA, 2005: 65-80).

No que diz respeito à construção civil, há uma apetência geral por parte dos migrantes, embora este seja um sector muito sazonal e que, durante o boom de obras públicas dos anos 80 e 90 do séc.XX, deu muito trabalho aos imigrantes em Portugal e Espanha. No primeiro caso os africanos são os que têm um maior tempo de permanência no ramo, embora se encontrem imigrantes de Leste e também indianos, estes últimos procurando a construção civil como uma forma de obterem capital para se estabelecerem por conta própria.

Numa análise por nacionalidades, estes autores constataram que, no caso espanhol, os alemães, os franceses e os italianos estão mais ligados à indústria (como quadros qualificados, trabalhadores por conta de outrem)); os portugueses ligados à construção civil, indústria e agricultura como operário ou trabalhadores não qualificados; os latino-americanos ao pequeno comércio, serviços recreativos, embora seja possível encontrar mexicanos, cubanos e venezuelanos na indústria (mais antigos); os africanos ligados à indústria (cabo-verdianos) e à agricultura (Gâmbia); os indianos e chineses trabalhar por conta própria ligados ao pequeno comércio, e os filipinos nos serviços domésticos. PAJARES (2001: 149) sublinha ainda o facto de os colectivos europeus (romenos, búlgaros e ucranianos) estarem mais concentrados na construção (sobretudo homens), seguido do comércio e da hotelaria (maioria mulheres) e com menor contingente no serviço doméstico e agrário. Os imi- 
grantes não comunitários desenvolvem a sua actividade económica no ramo da hotelaria, serviço doméstico, agricultura e construção, enquanto os comunitários trabalham no sector da indústria e em funções altamente qualificadas. Os primeiros são muitas vezes trabalhadores complementares da mãode-obra local que, em busca de uma melhor situação económica e social, ocupam postos de trabalho que não requerem grandes conhecimentos técnicos, e que não são apetecíveis pelos autóctones, daí que o autor sublinhe que não há necessidade de haver preocupação com a questão da concorrência laboral entre autóctones e alóctones. Os marroquinos estão mais concentrados na construção, seguidos do comércio, hotelaria e agricultura.

No caso português os africanos estão muito ligados à construção civil e serviços de limpeza, os brasileiros à restauração e hotelaria bem como serviços mais qualificados (área da saúde), sendo os europeus de Leste mais flexíveis em termos de sector de actividade. Os chineses, indianos e bangladeshis estão mais ligados ao comércio. Neste contexto FONSECA (2005: 104) refere que a construção civil é o sector onde há mais representação de imigrantes de todas as nacionalidades, seguido dos serviços (de limpeza) onde dominam as nacionalidades dos PALOP, enquanto na indústria e na agricultura há uma maior representação das nacionalidades da Europa de Leste (Ucrânia, Roménia, Rússia, etc.). Na hotelaria e restauração há uma maior representatividade dos brasileiros e também dos angolanos.

\section{CONCLUSÃO}

Embora com diferenças estruturais e conjunturais, pode verificar-se que Portugal e Espanha têm uma matriz emigratória similar que no final do século XX se assumiu também como imigratória. Feita uma abordagem onde se reflectiu sobretudo acerca da transição do paradigma migratório à escala peninsular com base numa breve abordagem histórica e na geografia da imigração associada ao mercado de trabalho, relacionando com momento de crise global em que vivemos, urge colocar uma questão: que futuro para a imigração na Península Ibérica?

Por um lado parece haver uma tendência para a continuidade dos fluxos imigratórios, por outro as comunidades alóctones estão mais reforçadas em termos quantitativos, o que se poderá traduzir no futuro na consolidação de canais migratórios onde circulará não só capital humano e social, mas também capital financeiro e cultural, numa lógica de aproximação e interacção entre os territórios de partida e de chegada. Por outro poderá verificar-se uma intensificação dos fluxos migratórios para o interior da Península, para regiões de baixas densidades populacionais, fruto da busca de oportunidades laborais em mercados de trabalho pouco explorados por parte dos imigran- 
tes. Não se crê que este fenómeno gere situações de concorrência, mas antes de complementaridade no tecido sócio-laboral, até porque tendencialmente se verifica que os estrangeiros tendem a desempenhar funções preteridas pelos autóctones.

A alteração das paisagens sociais e culturais é um aspecto que certamente continuará a redesenhar a matriz territorial da Península Ibérica, no sentido de lhe conferir não só um dinamismo multicultural topológico, como também uma necessidade de olhar para os imigrantes como parte integrante do todo, com um carácter dinâmico, transformador, que irão responder a muitas necessidades, ao mesmo tempo que lançarão desafios à comunidade de acolhimento numa lógica biunívoca, o que se traduzirá numa nova forma de ver, compreender, interpretar e interagir com o Outro.

\section{BIBLIOGRAFIA}

Actis, W.; De PradA, M. Á.; Pereda, C. (Colectivo IOÉ) (1999): Immigrantes, trabajadores, ciudadanos. Una visión de las migraciones desde España. Valência, Universitat de Valência, Patronat Sud-Nord.

BAGANHA, M. I.; FERRÃO, J.; MALHEIROS, J. M. (1998): «Immigrants and the labour market: the portuguese case». In: VICENTE, P. (Coord.), Metropolis International Workshop Proceedings (Lisbon, September 28-29, 1998), Lisboa, Fundação Luso-Americana para o Desenvolvimento, 89-120.

BAGANHA, M. I.; MARQUES, J. C.; FONSECA, G. (2000): Is an ethclass emerging in Europe? The portuguese case. Lisboa, Fundação Luso-Americana.

Baganha, M. I.; MARQues, J. C.; GóIS, P. (2009): «Imigrantes em Portugal: uma síntese histórica". Ler História - Emigração e Imigração Lisboa, Associação de Actividades Científicas, ISCTE, $n^{\circ}$ 56, 123-133.

BLANCO, C. (2000): Las migraciones contemporáneas. Madrid, Alianza Editorial.

CASADO FRANCISCO, M. (2005): Análisis económico de la inmigración en España: una propuesta de regulación. Madrid, Universidad Nacional de Educación a Distancia.

CRIADO, M. J. (2000): «La cuestión migratoria en España: datos y notas». In: Morente MejÍAs, F. (Ed.), Cuadernos Étnicos. Inmigrantes, Claves para el futuro inmediato. Jaén: Universidad de Jaén, Col. Monografías Jurídicas, Económicas y Sociales, Jaén, p.163-192.

Cuadrado Roura, J. R.; Iglesias Fernández, C.; Llorente Heras, R. (2007): Inmigración y mercado de trabajo en España (1997-2005). Bilbao, Fundación BBVA.

Esteves, M. do C. (Org.) (1991): Portugal, país de Imigração. Lisboa, Instituto de Estudos para o Desenvolvimento, Caderno ${ }^{\circ} 22$.

FONSECA, M. L. (2005): «Inserção territorial. Urbanismo, desenvolvimento regional e políticas locais de atracção». In: VITORINO, A. (Coord.), Imigração: oportunidade ou ameaça? Lisboa, Fundação Calouste Gulbenkian, Col.Principia, 105150 . 
Fonseca, M. L.; Malheiros, J.; Esteves, A.; CAldeIRA, M. J. (2002): Immigrants in Lisbon, routes of integration. Lisboa: Centro de Estudos Geográficos, Universidade de Lisboa, Estudos para o Planeamento Regional e Urbano, $\mathrm{n}^{\circ} 56$.

GARCÍA MARTíNEZ, C. (1997): «España, país de inmigración», en PANADERO MoyA, M.; GARCíA MARTínez, C. (Coords.), Migraciones extranjeras en la Unión Europea. Cuenca, Universidad de Castilla-La Mancha.

GozÁlvez PÉREZ, V.; LÓPEZ TRIGAL, L. (1999): «Jornaleros extranjeros en el campo español». Ería, no 49, 213-229.

GoZÁlvEZ PÉREZ, V. (2002a): «La inmigración en España: causas y perspectivas según el contexto europeo», en PASTOR ANTOLÍN, L. J. (Coord.), Globalización y migraciones hoy: diez años de contínuos desafíos. Valladolid, Universidad de Valladolid, Centro Buendia, 21-29.

GozÁlvez PÉREZ, V. (2002b): «El incremento de trabajadores extrangeros en la agricultura española: su necesaria regulación», en ALMOGUERA SALLENT, P. (Ed.), De sur a sur. Análisis multidisciplinar del fenómeno migratório en España. Sevilla, Universidad de Sevilla, 173-193.

IKUSPEGI (2007): «Inmigración y comunidades autónomas». Panorámica de la inmigración, $\mathrm{n}^{\mathrm{o}}$ 15, Bilbao, http://www.ikuspegi.org/documentos/ documentos_internos/ panoramica15cas.pdf (accedido en 01/06/2009)

IZQUIERDO ESCRIBANO, A. (2002): «La inmigración: reto europeo del siglo XXI» en RAmos, J. D. (Coord.), Hacia una Europa multicultural. El reto de las migraciones. Salamanca: Universidad Pontificia de Salamanca, Estudios no 243, 23-45.

LABRADOR FERNÁNDEZ, J. (2001):- Identidad e inmigración. Un estudio cualitativo con inmigrantes peruanos en Madrid. Madrid, Universidad Pontificia de Comillas.

LAmela Viera, C. ET Al. (2006): Demografía de los extranjeros. Incidencia en el crecimiento de la población. Bilbao, Fundación BBVA.

LóPez CASASNOVAS, G.; ARgullol, E. (Coords.) (2005): La razón principal para emigrar es la presencia de compatriotas en el lugar de destino, seguida de los niveles de pobreza y desempleo en el país de origen. Fundación BBVA.

http://www.documentalcayuco.org/documentos/Estudios/Estudio_BBVA.pdf (acedido em 25/05/2009).

LOPEZ TRIGAL, L. (Dir.) (1994): La migración de portugueses en España. León, Universidad de León.

MALHEIROS, J. (1996): Imigrantes na região de Lisboa. Os anos da mudança. Lisboa: Edições Colibri.

Malheiros, J. M. (2005): «Migrações», en MedeIRos, Carlos Alberto, Geografia de Portugal 2 - Sociedade, Paisagens e Cidades, Lisboa, Círculo de Leitores, 87-125.

MARTINS, A. C. (2006): Diagnóstico sobre a situação social dos imigrantes no concelho de Portalegre. Câmara Municipal de Portalegre.

http://www.cm-portalegre.pt/resources/4317/zoom/diagnportalegre.pdf (accedido en $04 / 06 / 2009$ )

MedeIRos, C. A. (1996): Geografia de Portugal. Ambiente natural e ocupação humana. Uma introdução. Lisboa, Editorial Estampa, 4 a edição. 
PAJARES, M. (2001): Inmigración y mercado de trabajo. Informe 2008. Madrid, Ministerio de Trabajo e Inmigración, Documentos del Observatorio Permanente de la Inmigración, $\mathrm{n}^{\circ} 17$.

Pumares Fernández, P.; García Coll, A.; HitA, Asensio, Á. (2006): La movilidad laboral y geográfica de la población extranjera en España. Madrid: Ministerio de Trabajo y Asuntos Sociales - Observatorio Permanente de la Inmigración, Documentos de OPI, $\mathrm{n}^{\circ} 10$.

Rocha-Trindade, M. B. (1995): Sociologia das Migrações. Lisboa, Universidade Aberta.

SALINAS RAmos, F. (2004): «La inmigración en España. Economía social e inserción sociolaboral», en SAlinas Ramos, F.; Herranz DE la CASA, J. M. (Dirs.), La economía social como puerta de integración sociolaboral de los inmigrantes. Ávila, Universidad Católica de Ávila, 31-62.

SANTOS, V. (2004): O discurso oficial do Estado sobre a emigração dos anos 60 a 80 e a imigração dos anos 90 à actualidade. Lisboa, ACIME, Observatório da Imigração.

SECRETARIA CONFEDERAL DE MigRACIONES (2006): Inmigración e mercado de trabajo "propuestas para la ordenación de los flujos". CCOO documentos. http://www.ccoo.es/comunes/temp/recursos/1/26125.pdf (accedido en 25/05/ 2009)

Urdiales Viedma, M. E.; Ferrer RodrígueZ, A. (2005): «La inmigración latinoamericana en España». Anales de Geografía, no 25, 115-134.

Velez de CASTRO, F.; CRAVIDÃO, F. (2008): «Immigration and public policies: thinking about local development? The Portuguese Case», en PRADHAN, P.; Wastl-Walter, D.; Folmar, S. (Eds.), Public policy and local development: opportunities and constraints, International Geographic Union, University of Thribuvan, 277-290. 